THURSDAY, OCTOBER 24, I872

\section{AGASSIZ AT SAN FRANCISCO}

THE completion of its labours by the United States 1 Hassler Expedition presents many points of almost dramatic interest. We have the veteran naturalist, a native of the little republic of the old world-having transferred his home to the great republic across the Atlantic, and settled himself to his scientific work at the University in Massachusetts which derives its name from the old seat of learning on the banks of the Cam,- there gathering about him a band of earnest students, the master and his disciples together building up at Cambridge, in the course of a few years, one of the best appointed schools for practical instruction in Natural Science, and one of the finest Museums of Comparative Zoology in the world. The citizens of the Great Republic are constantly discovering within their own vast territories some extraordinary natural production which in old times would have ranked among the great wonders of the world: now a grove of gigantic trees in California; now the marvellous cañons of Colorado; now a wonderful assemblage of hot springs and geysers in Nebraska. But not content with the Government exploration of their own domain, the munificence of a private citizen of Massachusetts fitted out this Hassler coasting survey expedition with the necessary appliances, and placed the veteran Agassiz at its head, for the purpose of investigating the natural features of the extremity of the Southern Continent, and the inhabitants of its seas, the latter department being specially placed under the management of the accomplished naturalists Pourtales and Steindachner. Our readers already know how the experienced eye of Agassiz detected in Patagonia the same evidences of extensive glacial action with which he was already so familiar in the northern hemisphere; and the contents of the dredging nets will furnish employment to the staff of American naturalists for many a month to come. After cruising up the Pacific Coast of South America, the voyage of the Hassler finally ended in United States territory at San Francisco, where the expedition met with such a reception as has probably never before been accorded to any body of scientific amateurs. The Alta California thus welcomes the great naturalist on his return to his adopted country :-

"San Francisco has in its midst a man of science than whom none in America, or out of it, more richly deserves the love and homage and respect of our people. He has come all the way around our Southern Continent, not for gold, as many came, not for silver, as many came, not for diamonds, as many would come or go, but for scientific knowledge, for discoveries in the hitherto unsearched waters of the seas, the unexhausted treasuries of Nature growing, budding, and blossoming along the shores of a continent. When such a man, if there be any other such, chances to visit a distant city, he is quite likely to be made the guest of it, to be fetted, and to be made to feel that his merits of head and heart have endeared him to the people, and that the city feels itself honoured particularly, instead of honouring him. All the dukes and princes that ever stepped foot in America, never deserved a tenth part of the attention which is due to Prof. Agassiz. There is in America no man living who, as a scientist, compares with this gentleman in acquirements in his lines of study, and in the triumphs achieved. Many of our No. 156 - vol. vi. citizens have called upon him, and extended such courtesies as private parties may, and perhaps quite as extensively as is agreeable to him. But the question is, what does this city owe to itself in this matter? A public reception by the city would be a very graceful courtesy extended to a very great and most worthy gentleman, and the honour to herself would be one of which every citizen might well be proud. We hope it may be done."

The same paper and the San Francisco Morning Bulletin both print full reports of the professor's address on the occasion of his reception in the Pacific Hall by the California Academy of Sciences, heading their article, in genuine American style, by sensation headers of the following description :-- Agassiz. Grand Reception under the Auspices of the California Academy of Sciences. Pacific Hall in a Blaze of Intellectual Light. From Polyp to Mammal. Modified Darwinism-The Prophecy and Advice of a Man of Science."

From the address itself we may be permitted to make a few extracts, for the purpose of illustrating what are the subjects that are now uppermost in the minds of our scientific friends on the other side of the Atlantic. But, first of all, let us cordially congratulate the representatives of Science in that remote State, on the honour which has been reciprocally conferred upon them and upon Agassiz and his fellow workers by the enthusiastic welcome which they have given him, and on the encouragement which his visit has afforded for the further prosecution of their arduous labours. In the words of Prof. Davidson, the Principal of the California Academy of Sciences :-

"Less than one month since, the great master of modern scientific thought and research addressed a few earnest students of science, who have patiently and bravely kept their lamp trimmed and burning. The magic of his words thrilled our hearts and cheered our hopes; but, best of all, that gave renewed confidence to friends who had an abiding faith in our efforts. That you might have a richer feast, we have prevailed upon him to break a long and comparative silence, when he most needed rest and repose. In less than one hour after our last Academy meeting, the seeds sown by him had borne fruit in giving to the Academy a greater number of life members than we had gathered in ten years. Within a fortnight the Agassiz Professorship of Oriental Languages and Literature was established for the Universities of California by the munificent endowment of our fellow citizen, the Hon. Edward Tompkins; and now, after eighteen or nineteen long years of arduous and desperate struggle with poverty in this State of marvellous wealth and boundless properity, the California Academy of Sciences is amply rewarded in being the instrument of introducing to the citizens of San Francisco Prof. Agassiz."

In the opening of his address, Prof. Agassiz made the following remarks on the present aims of science :-

"For the last three years I have been prevented from appearing in public, owing to the indifferent condition of my health. I venture this evening to address you. I have been asked to give some account of the voyage of the Hassler, which has terminated its cruise in the harbour of San Francisco. I am afraid that the incidents of that scientific expedition are too monotonous to be very entertaining; and willing as I am to accede to the request, I think I will submit to your attention remarks upon the present aims of Science, which may at least have a more solid foundation than our past efforts during that voyage, to increase the bases and material foundation of knowledge. Allow me to say that this examination, as I may call it, has been entirely incidental to the necessities of the Coast Survey. The good ship which brought us here is D D 


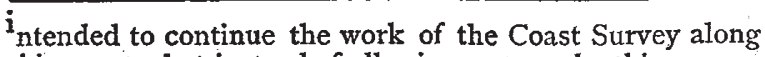
this coast; but instead of allowing us to make this voyage empty, some scientific gentlemen were invited by the Superintendent of the Coast Survey to take passage in her, and make the most of the opportunity. Liberal citizens of Massachusetts added means to the good will of the Superintendent-so that whatever collections and investigations should be made during the voyage should not be an additional expense to the great international undertaking, or to the Navy.

"I think it desirable that these facts should be known, in order that not too great expectations should be entertained concerning the scientific results of the Hassler's voyage; for all that which could be done was done by means supplied by private individuals, and not by the large resources of the Government. Unfortunately, it is almost everywhere still so, that Science has to take the humblest place in the world, as if equal opportunities were yet granted with a reluctant hand. It is only in recent times that the value of research begins to be felt; and I hope to live, old as I am, long enough to see the community, the enlightened community, which has become my second fatherland, appreciate what Science is doing for the general prosperity, and then contribute to the necessities of Science with that generous liberality which characterises the acts of the American people. It is not generally understood-and perhaps we scientific men are at fault in this matter-that Science is at the foundation of all natural progress in the community, in industry, in the arts, in almost everything."

After a few details as to the objects of the study of natural history, he proceeded to explain that "the only difficulty in the way of the study lies in the fact that there are no teachers; that the community lacks teachers in this department; and wherever there are a few educated, they are at once swallowed by the numerous institutions of learning which are organising everywhere. And we cannot educate a sufficient number of them, for the simple reason that there are other walks in life which are more promising in the rewards they secure for their devotees. So Science is always behindhand, and yet it is she who furnishes the primary material for all the progress in modern times."

We need not follow the speaker through his singular misrepresentation of the theory of evolution as taught in this country, viz., that the various forms of life, as we now see them, "may be the work of blind forces, of forces without intelligence, without discriminating power, and without forethought," and that the object of the study of nature is "to determine whether we ourselves are descended from monkeys or whether we are the work of a beneficent Father." We will rather pass on to his peroration, which sets forth some truths at least as applicable to us as to the audience he was addressing:-

"It will no longer do for the coming generation to say, I will accept this or that doctrine, because knowledge is pressing at your halls : but I will say to you, you may know it because you must know it, and unless you are willing to learn it you may grope in ignorance. That is the condition that stares us in the face for the future, and it becomes on that account the duty of every man to foster knowledge and to prepare the coming generation with all those appliances which lead to an independent opinion on all those matters. And that question is pressed upon you for the first time. You have for the first time in your existence as a State a generation which is about ready to enter the University. You have not had that in past generations, in past years, but your children approach the time when they may prepare for college. It is your duty that you have, then, a college which will set measures of the highest aspiration for the coming generation. And you cannot be willing to depend for their education upon the bounty of other States when in your prosperity, when you have rivalled all civilised communities. When I see luxury here, as in the oldest States of the world; when I see here the appliances for all the efforts of man carried to the highest degree, are you willing that your children should go and beg for information at the doors of other countries? It is for you to educate them and to give them those means which will make them find at home those advantages which otherwise you will have to seek for them by parting with them during those very years when their character is shaping. But there is another consideration than that of your immediate necessities here. No community can be utterly great without culture. Culture is the background of every great community. It is, in fact, the true and only test of real greatness."

Are not we in this country also forcing our children " to go and beg for information at the doors of other countries"? As long as we do not provide at home those educational advantages which so many go abroad to seek, we must submit to have to sit at the feet of our own daughter, and to learn from America both how to honour our really great men, and how to attain that scientific position among the nations to which our wealth and our material resources entitle us. The lesson is hard to learn, but it is one which must be learnt either by us or our children; and the longer we leave the task unlearnt, the harder will it be to learn.

\section{RAILWAYS AND SCIENCE}

Life of Richard Trevithick, with an Account of his Inventions. By Francis Trevithick, C.E. 2 vols. (London : E. and F. Spon, I872.)

Life and Labours of Mr. Brassey, 1805-1870. By Arthur Helps. (London: Bell and Daldy, 1872.)

Railways or no Railways; or, The Battle of the Gauges Renewed. By Robert F. Fairlie. (London: Effingham Wilson, 1872.)

THESE three works are directly concerned with railways, though each of them deals with a different aspect of the many-sided subject. . It would be out of place in these columns to review in detail each of the publications; they may, however, suggest a few thoughts not inappropriate to the columns of a scientific periodical.

The first on the list takes us back to the birth of the steam-engine, carrying us on through its chequered and roughly-handled youth to the time when it was fairly set agoing on that wonderful career, by means of which the whole face of the earth has been changed as if by the breath of a god, the relationships of nations and of men altered entirely, and civilisation hurried on at a rate almost bewildering. The benefits conferred on humanity by the discovery of the simple scientific principle on which the steam-engine rests, are incalculable, and not to be realised in anything like their fulness by those who, like most now living, have been born to these benefits, and who can only grumble that the advantages of the legacy left them are not by any means what they might be, were they not marred by the officiousness, the avarice, the prejudices, and the blundering stupidity of those who have constituted themselves its trustees. That this has 